\title{
Perbedaan Status Gizi dan Pola Jajan Anak Sekolah Dasar di Jakarta Berdasarkan Rutinitas Sarapan
}

\section{Differences in Nutritional Status and Snacking Patterns in School Age Children in Jakarta Based on Breakfast Routinity}

\author{
Nunung Cipta Dainy ${ }^{(1)}$, Fauza Rizqiya ${ }^{(1)}$, Walliyana Kusumaningati ${ }^{(1)}$, Wilda Yunieswati $^{(1)}$ \\ ${ }^{(1)}$ Program Studi Gizi, Fakultas Kedokteran dan Kesehatan \\ Universitas Muhammadiyah Jakarta, Indonesia
}

Korespondensi Penulis: Nunung Cipta Dainy, Program Studi Gizi

Fakultas Kedokteran dan Kesehatan, Universitas Muhammadiyah Jakarta

Email: nciptadainy@gmail.com

\begin{abstract}
ABSTRAK
Sarapan dengan menu bergizi seimbang adalah salah satu pilar gizi seimbang. Namun faktanya masih banyak yang meninggalkan sarapan, termasuk anak sekolah. Studi ini bertujuan untuk mengetahui gambaran kebiasaan sarapan, kebiasaan jajan siswa sekolah MI Al-Falah Jakarta terhadap status gizi. Metode yang digunakan cross sectional pada 70 orang siswa sekolah MI Al-Falah yang terdiri dari siswa kelas empat dan lima. Pengambilan data dilakukan dengan menggunakan kuesioner terstruktur. Pengukuran status gizi meliputi berat badan dan tinggi badan dilakukan menggunakan timbangan digital dan mikrotoise. Perhitungan IMT/U dilakukan menggunakan software WHO AnthroPlus. Analisis data menggunakan uji beda independent t-test. Hasil studi menunjukkan bahwa tidak terdapat perbedaan status gizi antara anak yang rutin sarapan dengan yang jarang sarapan ( $\mathrm{p}$ value $>0,05)$, namun terdapat perbedaan berat badan yang signifikan antara anak yang rutin sarapan dengan yang jarang sarapan $(\mathrm{p}$ value $=0,018)$. Berat badan juga berbeda signifikan berdasarkan kebiasaan sarapan dengan menu hasil memasak dirumah atau membeli ( $\mathrm{p}$ value $=0,020)$. Tidak ada perbedaan frekuensi jajan di sekolah antara siswa yang rutin sarapan ataupun jarang sarapan ( $\mathrm{p}$ value $>0,05$ ). Kesimpulannya sarapan atau tidak, anak-anak tetap melakukan jajan di sekolah dan melewatkan sarapan mungkin menyebabkan kelebihan berat badan.
\end{abstract}

Kata kunci: Anak Sekolah, Berat Badan, Jajan, Sarapan, Status Gizi

\section{ABSTRACT}

Breakfast with a balanced nutritious menu is one of the pillars of balanced nutrition. But the fact is there are still many people who leave breakfast, including school-age children. This study aims to determine the description of breakfast habits, snack habits of MI Al-Falah Jakarta students on nutritional status. The method used was crosssectional among $70 \mathrm{MI}$ Al-Falah school students consisting of fourth and fifth-grade students. Retrival of data using a structured questionnaire. Measurement of body weight and height used digital scale and microtoise. Calculation of BMI / A used WHO AnthroPlus. Data analyzsis used independent t-test. The results of the study showed that there was no difference in nutritional status between children who had breakfast regularly and rarely ( $p$-value > 0.05), but there were significant differences in body weight between children who regularly had breakfast and rarely ( $p$-value $=0.018)$. Bodyweight also differed significantly based on breakfast habits with home cooking or bought menus ( -value $=0.020)$. There is no difference in the frequency of snacks at school between students who regularly breakfast or rarely (p-value > 0.05). The conclusion is whether breakfast or not, children will still have snacks at school, and skipping breakfast may result in excess weight.

Keywords: Bodyweight, Breakfast, Nutritional Status, School-Age Children, Snacking 


\section{PENDAHULUAN}

Saat ini jargon Sumber Daya Manusia (SDM) Unggul Indonesia Maju sudah dicanangkan oleh pemerintah. Untuk mencapai SDM unggul tentu salah satu upayanya adalah memastikan para calon generasi bangsa ini mendapatkan asupan gizi yang kualitasnya baik dan jumlahnya mencukupi kebutuhan. Anak usia sekolah merupakan calon generasi bangsa yang juga merupakan kelompok rawan terjadinya kurang gizi. Untuk mencapai status gizi yang baik setiap anak sekolah harus mengaplikasikan pilar gizi seimbang salah satunya adalah sarapan setiap pagi.

Sarapan sangat penting sebagai sumber energi awal untuk beraktivitas. Pada anak sekolah, sarapan berhubungan dengan prestasi anak. Namun fakta nya masih banyak anak sekolah yang meninggalkan sarapan. Serangkaian rutinitas pagi yang harus cepat dilakukan mengakibatkan kegiatan sarapan menjadi tidak prioritas. Hasil penelitian Brata et al., (2016) menunjukkan bahwa siswa salah satu SDN di Jakarta Barat yang melewatkan sarapan sebanyak 44\%. Rosyidah dan Andrias juga menemukan bahwa siswa salah satu SDN di Surabaya melewatkan sarapan sebanyak 32,7\% (Rosyidah \& Andrias, 2013). Nuryani dan Rahmawati menyatakan bahwa siswa di Gorontalo juga banyak yang melewatkan sarapan yakni sebanyak 35,1\% (Nuryani \& Rahmawati, 2018).

Pada tahun 1960-an ahli gizi Adelle Davis menyatakan suatu pepatah bahwa "makan sarapan seperti raja, makan siang seperti pangeran dan makan malam seperti orang miskin" (AK, 2018). Pepatah tersebut mengisyaratkan bahwa sarapan sangat penting dibandingkan waktu makan yang lain, sehingga dianalogikan dengan makanan raja. Namun saat ini yang terjadi sebaliknya, sarapan dengan makanan seadanya bahkan tidak sarapan, kemudian makan siang dan makan malam dengan menu yang lengkap. Hal-hal yang mungkin dapat menjadikan sarapan tidak dilakukan khususnya pada anak sekolah antara lain terlambat bangun, kurangnya waktu, kurang nafsu makan, atau ketidakmampuan orang tua untuk menyediakan sarapan.

Kebiasaan melewatkan sarapan berhubungan dengan kegemukan (Rosyidah \& Andrias, 2013). Di Indonesia, prevalensi nasional kegemukan pada anak usia sekolah mengalami peningkatan. Hasil Riset Kesehatan Dasar tahun 2010 dan 2013 menunjukkan prevalensi nasional kegemukan pada anak sekolah (5-12 tahun) meningkat dari 9,2\% menjadi 18,8\% dan angka tertinggi terdapat di DKI Jakarta $(30,1 \%)$ (Kemenkes RI, 2010; Kemenkes RI, 2013). Angka tersebut jauh melampaui prevalensi nasional, sehingga dapat dikatakan bahwa masalah kegemukan di DKI Jakarta sudah merupakan masalah yang harus segera diatasi. Kebiasan melewatkan sarapan selain berpengaruh terhadap status gizi, juga berpengaruh terhadap penurunan performa siswa di sekolah seperti tingkat kehadiran, nilai ujian dan keikutsertaan dalam kegiatan ekstrakurikuler (Rampersaud et al., 2005).

Anak yang melewatkan sarapan akan cenderung lebih banyak membeli jajanan di luar rumah ataupun di sekolah. Makanan jajanan diluar rumah seringkali tidak memenuhi mutu dari segi gizi, higienitas dan keamanan pangan. Jajanan adalah makanan dan atau minuman yang dijual di tempat-tempat umum, dapat langsung dikonsumsi tanpa perlu diolah atau dipersiapkan lagi. Jenis makanan jajanan yang terdapat di sekolah sangat beraneka ragam. Namun sebagian besar biasanya merupakan jajanan yang tinggi kalori (karbohidrat dan lemak) dan rendah serat, vitamin mineral. Hal tersebut dapat menjadi penyebab obesitas pada anak (Utter et al., 2007; Manalu \& Suudi, 2017).

Badan POM RI merilis data Pangan Jajanan Anak Sekolah (PJAS) tahun 2009 yang menunjukkan bahwa 45\% PJAS tidak memenuhi mutu dan keamanan pangan dikarenakan mengandung bahan kimia berbahaya, Bahan Tambahan Pangan (BTP) yang melebihi batas aman, serta adanya cemaran mikrobiologi (BPOM RI, 2009). Jika anak-anak mengonsumsi jajanan tersebut maka dapat menyebabkan gangguan kesehatan dan berisiko pada status gizi anak. Oleh karena itu nilai sarapan untuk anak sekolah menjadi lebih tinggi dibandingkan untuk kelompok usia lain, sehingga penelitian ini penting untuk dilakukan.

Studi ini bertujuan untuk mengetahui gambaran kebiasaan sarapan dari aspek frekuensi dan cara mendapatkan menu sarapan, terkait dengan gambaran kebiasaan jajan, dan perbedaan status gizi siswa sekolah MI AlFalah.

\section{SUBYEK DAN METODE}

Studi ini menggunakan desain crosssectional dengan responden siswa sekolah dasar 
MI Al Falah Jakarta sebanyak 70 orang. Pengambilan data dilakukan pada bulan April 2019 di sekolah dasar MI Al Falah. Responden penelitian ini adalah siswa MI Al Falah yang memenuhi kriteria inklusi sebagai berikut: (1) Siswa atau siswi kelas 4 atau kelas 5; (2) sehat; (3) dapat berkomunikasi dengan baik; (4) mampu membaca dan menulis. Instrumen yang digunakan berupa kuesioner terstruktur yang disusun oleh tim peneliti mengacu pada penelitian Suryaalamsyah (Suryaalamsah et al., 2019). Responden mengisi kuesioner bersamasama dengan dipandu oleh tim peneliti. Data yang dikumpulkan adalah karakteristik siswa (nama, kelas, usia, jenis kelamin, jumlah bersaudara, jumlah uang saku), kebiasaaan sarapan (frekuensi sarapan dalam satu pekan, waktu sarapan, menu sarapan), kebiasaan jajan (frekuensi jajan, jenis jajanan yang dibeli, tempat membeli jajan) serta pengukuran antropometri (berat badan dan tinggi badan).

Alat untuk mengukur berat badan adalah timbangan digital merek Kris (lisensi dari Camry) dengan ketelitian $0,01 \mathrm{~kg}$. Adapun alat untuk mengukur tinggi badan adalah stadiometer portable (microtoise) dengan ketelitian $0,1 \mathrm{~cm}$. Penentuan status gizi siswa berdasarkan Indeks Massa Tubuh terhadap umur (IMT/U). IMT dihitung berdasarkan berat badan dan tinggi badan anak. Adapun kategori status gizi berdasarkan IMT/U adalah: kurus (Zskor $<-2)$, normal $(-2 \leq$ Zskor $\leq 1)$, berat badan lebih $(1<$ Zskor $\leq 2)$, dan gemuk (Zskor $>$ 2). Perhitungan Zskor dilakukan menggunakan software WHO AthroPlus.

Pengolahan data dengan melakukan pengkodean data berdasarkan kelompok siswa yang jarang sarapan sebelum berangkat sekolah (sarapan 1-2 kali/pekan), dan kelompok siswa yang rutin sarapan sebelum berangkat sekolah
(3-6 kali/pekan). Satu pekan sekolah adalah sebanyak enam hari efektif sekolah (SeninSabtu). Analisis statistik menggunakan statistik deskriptif untuk data univariat. Adapun untuk data bivariat menggunakan uji independent t-test pada selang kepercayaan $95 \%$.

\section{HASIL}

Karakteristik responden berdasarkan jenis kelamin sebanyak $40 \%$ siswa laki-laki, dan $60 \%$ siswa perempuan. Usia siswa sebagian besar $>10$ tahun. Tabel 1 menunjukkan bahwa sebanyak 41 orang siswa $(58,6 \%)$ menyatakan jarang sarapan dan sisanya sebanyak 29 orang $(41,4 \%)$ menyatakan rutin sarapan. Berdasarkan pengelompokkan jarang dan rutin sarapan, masih terdapat siswa yang berusia kurang dari 10 tahun yakni 12,2\% di kelompok siswa jarang sarapan dan 44,8\% di kelompok siswa yang rutin sarapan.

Besar keluarga dapat mempengaruhi kebiasaan sarapan dalam suatu keluarga. Pada penelitian ini besar keluarga dilihat dari jumlah saudara kandung. Tabel 1 menunjukkan bahwa pada kelompok siswa yang jarang sarapan sebagian besar memiliki jumlah saudara kandung lebih dari satu orang $(53,7 \%)$, sedangkan kelompok siswa yang rutin sarapan sebagian besar memiliki satu saudara $(62,1 \%)$.

Karakteristik lain yang diamati dalam penelitian ini adalah besaran uang saku siswa. Rata-rata uang saku siswa adalah sebesar Rp. 12.029,- (dua belas ribu dua puluh sembilan rupiah). Kedua kelompok siswa baik yang jarang sarapan maupun rutin sarapan sebagian besar membawa uang saku ke sekolah sebesar Rp. 12.000,-. 
29 Nunung Cipta Dainy, Fauza Rizqiya, Walliyana Kusumaningati, Wilda Yunieswati Perbedaan Status Gizi...

Tabel 1. Karakteristik Siswa MI Al Falah Berdasarkan Kelompok yang Jarang dan Rutin Sarapan

\begin{tabular}{ccccc}
\hline Karakteristik & \multicolumn{2}{c}{ Jarang } & \multicolumn{2}{c}{ Rutin } \\
\cline { 2 - 5 } & $\mathbf{n = 4 1}$ & $\mathbf{\%}$ & $\mathbf{n = 2 9}$ & $\mathbf{\%}$ \\
\hline Jenis Kelamin & & & & \\
Laki-laki & & & 11 & 37,9 \\
Perempuan & 17 & 41,5 & 18 & 62,1 \\
\hline Usia & 24 & 58,5 & & \\
$\leq 10$ tahun & 5 & 12,2 & 13 & 44,8 \\
$>10$ tahun & 36 & 87,8 & 16 & 55,2 \\
\hline Jumlah bersaudara & & & & \\
$\leq 2$ bersaudara & 19 & 46,3 & 18 & 62,1 \\
$>2$ bersaudara & 22 & 53,7 & 11 & 37,9 \\
\hline Uang Saku & & & & \\
$\leq$ Rp.12.000,- & 23 & 56,1 & 24 & 82,8 \\
$>$ Rp.12.000,- & 18 & 43,9 & 5 & 17,2 \\
\hline
\end{tabular}

Tabel 2. Distribusi Status Gizi Siswa Berdasarkan Indeks Massa Tubuh Terhadap Umur

\begin{tabular}{ccccc}
\hline \multirow{2}{*}{ Status Gizi } & \multicolumn{2}{c}{ Jarang sarapan } & \multicolumn{2}{c}{ Rutin sarapan } \\
\cline { 2 - 5 } & $\mathbf{n = 4 1}$ & $\mathbf{\%}$ & $\mathbf{n = 2 9}$ & $\mathbf{\%}$ \\
\hline Kurus & 2 & 4,9 & 2 & 6,9 \\
\hline Normal & 23 & 56,1 & 19 & 65,5 \\
\hline Berat badan Lebih & 4 & 9,7 & 6 & 20,7 \\
\hline Gemuk & 12 & 29,3 & 2 & 6,9 \\
\hline
\end{tabular}

Hasil pengukuran berat badan dan tinggi badan siswa menjadi data untuk menentukan indeks massa tubuh terhadap umur. Tabel 2 menunjukkan bahwa sebagian besar siswa memiliki status gizi normal, $56,1 \%$ pada kelompok siswa yang jarang sarapan dan $65,5 \%$ pada kelompok siswa yang rutin sarapan. Hal yang menarik dalam data status gizi pada Tabel 2 terlihat bahwa jumlah siswa yang jarang sarapan mengalami obesitas cukup tinggi, yakni sebanyak 29,3\%.

Adapun siswa yang obesitas pada kelompok yang rutin sarapan hanya sebesar
6,9\%. Jika kategori gizi lebih digabungkan maka jumlah siswa yang gizi lebih di kelompok yang jarang sarapan sebanyak 39,0\%, dan pada kelompok yang rutin sarapan terdapat $27,6 \%$. Selain gizi lebih, siswa MI Al Falah juga terdapat siswa yang gizi kurang, masingmasing kelompok terdapat dua orang yang masuk kedalam kategori kurus. Hal ini mengindikasikan bahwa dengan tingginya masalah gizi lebih di DKI Jakarta, masalah gizi kurang masih belum tuntas diatasi. 
Tabel 3. Uji Beda Nilai Rata-Rata Berat Badan, Tinggi Badan, Indeks Massa Tubuh Terhadap Umur dan Kebiasaan Jajan Siswa

\begin{tabular}{cccc}
\hline Variabel & $\begin{array}{c}\text { Jarang sarapan } \\
\mathbf{n = 4 1}\end{array}$ & $\begin{array}{c}\text { Rutin sarapan } \\
\mathbf{n = 2 9}\end{array}$ & P value \\
\hline Berat Badan & $39,7 \pm 12,1$ & $32,8 \pm 8,7$ & $0,018^{*}$ \\
\hline Tinggi Badan & $141,2 \pm 8,0$ & $136,0 \pm 7,6$ & 0,613 \\
\hline $\begin{array}{c}\text { Indeks Massa } \\
\text { Tubuh/umur }\end{array}$ & $0,595 \pm 1,7$ & $0,094 \pm 1,5$ & 0,204 \\
\hline Frekuensi Jajan & $3,63 \pm 0,73$ & $3,45 \pm 0,87$ & 0,073 \\
\hline
\end{tabular}

Tabel 4. Uji Beda Nilai Rata-Rata Berat Badan, Tinggi Badan, Indeks Massa Tubuh Terhadap Umur Berdasarkan Menu Sarapan

\begin{tabular}{cccc}
\hline Variabel & $\begin{array}{c}\text { Membeli } \\
\mathbf{n = 2 3}\end{array}$ & $\begin{array}{c}\text { Memasak } \\
\mathbf{n = 4 7}\end{array}$ & P value \\
\hline Berat Badan & $37,9 \pm 13,6$ & $36,3 \pm 10,0$ & $0,020^{*}$ \\
\hline Tinggi Badan & $140,3 \pm 8,8$ & $138,4 \pm 7,9$ & 0,373 \\
\hline Massa Tubuh/umur & $0,242 \pm 1,8$ & $0,459 \pm 1,5$ & 0,111 \\
\hline
\end{tabular}

Uji beda nilai rata-rata dilakukan terhadap variabel berat badan, tinggi badan, indeks massa tubuh terhadap umur dan frekuensi jajan siswa. Tabel 3 menunjukkan bahwa terdapat perbedaan nilai rata-rata yang signifikan pada variabel berat badan antara kelompok siswa yang jarang sarapan dengan siswa yang rutin sarapan. Terlihat bahwa kelompok siswa yang jarang sarapan memiliki nilai rata-rata berat badan yang lebih tinggi secara signifikan. Adapun variabel lainnya tidak berbeda nyata, walaupun secara nilai terlihat bahwa kelompok siswa yang jarang sarapan memiliki rata-rata tinggi badan, IMT/U dan frekuensi jajan yang lebih tinggi daripada siswa yang rutin sarapan.

Rata-rata berat badan kelompok siswa yang jarang sarapan termasuk dalam kategori berlebih, karena standar rata-rata berat badan anak usia 10 tahun adalah sebesar $33,1 \mathrm{Kg}$ (Muljati et al., 2016). Adapun rata-rata berat badan kelompok siswa yang rutin sarapan telah mendekati nilai standar.

Menu sarapan siswa MI Al Falah diperoleh dengan dua cara, yaitu hasil dari membeli dan hasil dari memasak di rumah. Tabel 4 menunjukkan bahwa sebanyak 23 orang siswa $(32,9 \%)$ mengonsumsi menu sarapan hasil dari membeli, sedangkan sisanya 47 orang $(67,1 \%)$ mengonsumsi menu sarapan yang dimasak di rumah. Data pada Tabel 4 juga memperlihatkan bahwa terdapat perbedaan signifikan rata-rata berat badan siswa ( $\mathrm{p}$ value
$=0,020)$. Kelompok siswa yang jarang sarapan memiliki rata-rata berat badan yang lebih tinggi dibandingkan dengan siswa yang rutin sarapan.

\section{DISKUSI}

Jumlah siswa MI Al Falah Jakarta yang jarang sarapan sangat tinggi hingga mecapai $58,6 \%$. Jumlah tersebut jauh lebih tinggi daripada hasil penelitian Brata et al (2016), Rosyidah dan Andrias (2015) dan penelitian Nuryani dan Rahmawati (2018). Dilihat dari karakteristik besar keluarga, kelompok siswa yang jarang sarapan sebagian besar memiliki lebih dari satu saudara $(53,7 \%)$, sedangkan yang rutin sarapan sebagian besar adalah keluarga kecil (hanya memiliki satu saudara kandung) $(62,1 \%)$. Besar keluarga dapat menjadi salah satu factor penyebab anak melewatkan sarapan. Orang tua dengan banyak anak memerlukan waktu lebih banyak di pagi hari untuk mempersiapkan anak-anaknya berangkat ke sekolah. Jika tidak dapat membuat strategi yang baik, maka banyak orang tua yang akhirnya memberikan uang jajan lebih tinggi agar anak dapat membeli sarapan di sekolah atau jajan yang lebih banyak.

Status gizi siswa berdasarkan IMT/U tidak terdapat perbedaan yang signifikan antara kelompok yang jarang sarapan dengan yang rutin sarapan. IMT dihitung berdasarkan berat badan dan tinggi badan anak, walaupun IMT/U tidak berbeda namun terdapat perbedaan berat badan yang signifikan. Siswa yang jarang 
sarapan memiliki rata-rata berat badan yang lebih tinggi dibandingkan dengan siswa yang rutin sarapan. Terdapat $29,3 \%$ siswa obes pada kelompok yang jarang sarapan. Hal ini sesuai dengan hasil penelitian Lawman yang menyatakan bahwa siswa yang tidak sarapan memiliki berat badan yang lebih tinggi (Lawman et al., 2014). Hasil penelitian Nuru dan Mamang juga menyatakan hal yang serupa bahwa melewatkan sarapan memiliki berpengaruh pada tubuh anak-anak terutama indeks massa tubuh (BMI) (Nuru \& Mamang, 2015).

Nilai kejadian obesitas pada siswa MI Al Falah sebanyak 29,3\% adalah angka yang cukup tinggi karena diatas prevalensi obesitas nasional pada anak sekolah $(18,8 \%)$. Di sisi lain angka ini mengambarkan kesesuaian dengan prevalensi obesitas anak sekolah di DKI Jakarta yang memang paling tinggi se-Indonesia yaitu 30,1\% (Kemenkes RI, 2013). Artinya masalah obesitas di DKI Jakarta memang benar-benar nyata adanya dan perlu segera ditangani dengan serius salah satunya dengan mengkampanyekan sarapan sehat tidak hanya pada anak sekolah tetapi pada semua tingkatan masyarakat. Hal tersebut penting karena anak sekolah yang tidak sarapan belum tentu dikarenakan keinginan pribadinya, namun juga dimungkinkan karena orang tua tidak menyiapkan sarapan karena tidak paham pentingnya sarapan tertutama bagi anak sekolah.

Mereka yang tidak sarapan akan merasa kurang kenyang, menambah nafsu makan dan menginginkan porsi besar pada waktu makan berikutnya. Hal ini mengakibatkan energy density lebih tinggi daripada anak yang sarapan. Melewatkan sarapan dapat menurunkan kesehatan anak-anak terutama efek domino dari kenaikan berat badan. Konsumsi sarapan adalah cara untuk memastikan bahwa anak sekolah memenuhi asupan nutrisi dan energi harian mereka.

Selain meningkatkan porsi pada waktu makan berikutnya, melewatkan sarapan juga dapat meningkatkan kecenderungan untuk mengonsumsi cemilan atau jajanan. Lani menyatakan bahwa selain sarapan konsumsi jajanan juga berpengaruh terhadap besar nilai IMT (Lani et al., 2017) Adapun jajanan yang terdapat di sekitar sekolah MI Al Falah adalah jenis jajanan yang tinggi kalori rendah serat. Salah satu contohnya adalah minuman manis, makanan berbasis tepung, dan gorengan. Ratarata frekuensi jajan siswa yang jarang sarapan dengan yang rutin sarapan tidak berbeda nyata. Namun rata-rata besar uang saku siswa yang jarang sarapan lebih besar daripada siswa yang rutin sarapan (berurutan: Rp. 13.220,- dan Rp. 10.345,-). Hal ini menunjukkan bahwa siswa yang jarang sarapan dengan frekuensi jajan yang sama dapat membeli lebih banyak makanan jajanan daripada siswa yang rutin sarapan.

Pemilihan menu bergizi seimbang saat sarapan sangat penting untuk dilakukan. Hal tersebut untuk memastikan bahwa semua komponen gizi yang diperlukan terpenuhi dalam menu sarapan. Menu sarapan bergizi seimbang haruslah mengandung karbohidrat, protein, lemak, vitamin, mineral serta serat. Menu sarapan siswa MI Al Falah secara umum adalah nasi dengan lauk-pauk. Sumber makanan untuk sarapan diperoleh dari memasak atau membeli. Menu sarapan dengan hasil masakan orang tua diantaranya adalah nasi goreng, nasi putih dengan telur goreng atau naget, mie dengan telur. Adapun menu sarapan hasil membeli diantaranya adalah: nasi uduk, nasi ulam, nasi kuning, bubur ayam.

Hasil uji beda menunjukkan bahwa terdapat perbedaan berat badan antara siswa yang mengonsumsi menu hasil memasak di rumah dengan menu hasil membeli. Siswa yang sarapan dengan menu hasil membeli memiliki berat badan yang lebih tinggi. Hal ini dapat dimungkinkan karena porsi makanan hasil membeli lebih besar dibandingkan dengan porsi makanan yang dimasak di rumah. Data yang dikumpulkan menunjukkan bahwa anak-anak mengonsumsi satu porsi nasi uduk/nasi ulam/nasi kuning untuk sarapan. Adapun satu porsi nasi uduk/nasi ulam/nasi kuning tersebut adalah sama dengan porsi sarapan untuk usia dewasa.

Berbeda dengan menu sarapan di rumah, anak-anak dapat dengan bebas mengurangi ataupun menambah porsi makan sesuai dengan kebutuhan. Hasil studi ini menguatkan akan pentingnya peran orang tua dalam menciptakan suasana agar anak-anak sarapan sebelum berangkat ke sekolah. Terbiasa sarapan saja tidaklah cukup, jenis menu sarapan pun penting untuk diperhatikan.

Keterbatasan studi ini adalah pemilihan lokasi penelitian menggunakan teknik purposive dengan pertimbangan kemudahan akses dan ijin penelitian sehingga hasil penelitian tidak dapat digeneralisir untuk sekolah lain. Namun kelebihannya dengan 
teknik ini kepatuhan responden menjadi lebih baik dan pengambilan data langsung dilakukan oleh tim peneliti, sehingga mengurangi kemungkinan adanya bias data.

\section{KESIMPULAN}

Siswa sekolah MI Al-Falah Jakarta yang tidak terbiasa sarapan sebanyak 41 orang $(58,6 \%)$. Sebanyak 23 orang $(32,9 \%)$ siswa sarapan dengan menu hasil membeli. Rata-rata uang jajan siswa sekolah MI Al-Falah Jakarta adalah Rp.12.000,- (dua belas ribu rupiah) dengan frekuensi jajan pada kategori sering (35 hari/ 6 hari). Terdapat perbedaan rata-rata berat badan yang signifikan ( $\mathrm{p}$ value $<0,05$ ) antara kelompok siswa yang jarang dengan yang rutin sarapan, serta antara kelompok siswa yang menu sarapannya membeli dengan menu masakan orang tua dirumah. Siswa yang tidak sarapan dan siswa yang sarapan dengan menu hasil membeli memiliki berat badan yang lebih tinggi. Orang tua sebaiknya menyediakan menu sarapan bergizi seimbang serta menarik minat anak untuk sarapan, sehingga anak-anak tidak membeli menu sarapan di luar rumah yang cenderung tinggi kalori rendah serat, vitamin dan mineral.

\section{UCAPAN TERIMAKASIH}

Ucapan terimakasih disampaikan kepada Kepala Sekolah MI Al Falah Jakarta yang telah memberikan ijin untuk melakukan pengambilan data. Ucapan terimakasih juga disampaikan kepada pimpinan Universitas Muhammadiyah Jakarta, Fakultas Kedokteran dan Kesehatan, Prodi Gizi atas bantuan dana sehingga kegiatan ini berjalan sesuai dengan rencana.

\section{DAFTAR PUSTAKA}

AK, M. (2018). Skipping Breakfast Everyday Keeps Well-being Away. Journal of Food Science and Nutrition Research, 01(01), 1-7. https://doi.org/10.26502/jfsnr.26421100003

BPOM RI. (2009). Pangan jajanan anak sekolah. Balai Besar POM.

Brata AM, Melani V, S. L. (2016). No Title. In Skripsi. Jakarta.

Kementerian Kesehatan RI. (2013). Riset Kesehatan Dasar 2013. Badan Penelitian Dan Pengembangan Kesehatan, 306.

Kementrian Kesehatan RI. (2010). Riset Kesehatan Dasar 2010. Badan Penelitian
Dan Pengembangan Kesehatan, 78. Retrieved from http://www.riskesdas.litbang.depkes.go.i d/download/TabelRiskesdas2010.pdf

Lani A, Margawati A, F. D. (2017). Hubungan frekuensi sarapan dan konsumsi jajan dengan z-score imt/u pada siswa sekolah dasar. Journal of Nutrition College, 6(4), 277-284.

Lawman, H. G., Polonsky, H. M., Vander Veur, S. S., Abel, M. L., Sherman, S., Bauer, K. W., ... Foster, G. D. (2014). Breakfast patterns among low-income, ethnicallydiverse 4 th -6 th grade children in an urban area. BMC Public Health, 14(1), 19. https://doi.org/10.1186/1471-2458-14604

Manalu, H. S. P., \& Suudi, A. (2017). Kajian Implementasi Pembinaan Pangan Jajanan Anak Sekolah (PJAS) untuk Meningkatkan Keamanan Pangan: Peran Dinas Pendidikan dan Dinas Kesehatan Kota. Media Penelitian Dan Pengembangan Kesehatan, 26(4), 249256.

https://doi.org/10.22435/mpk.v26i4.5734 $.249-256$

Muljati, S., Triwinarto, A., Utami, N., \& Hermina. (2016). Gambaran Median Tinggi Badan Dan Berat Badan Menurut Kelompok Umur Pada Penduduk Indonesia Yang Sehat Berdasrkan Hasil Riskesdas 2013 (Description Of Median Number Of Weight And Height Classeified By Age Group On Healthy Indonesian Citizens Based On Riske. Penelitian Gizi Dan Makanan, 39(2), 137-144.

Nuru, H., \& Mamang, F. (2015). Impact of breakfast skipping toward children health: a review. International Journal of Community Medicine and Public Health, 2(3), 201-209. https://doi.org/10.18203/23946040.ijcmph20150473

Nuryani, N., \& Rahmawati, R. (2018). Kebiasaan jajan berhubungan dengan status gizi siswa anak sekolah di Kabupaten Gorontalo. Jurnal Gizi Indonesia, $\quad 6(2), \quad 114$. https://doi.org/10.14710/jgi.6.2.114-122

Rampersaud, G. C., Pereira, M. A., Girard, B. L., Adams, J., \& Metzl, J. D. (2005). Breakfast habits, nutritional status, body weight, and academic performance in 
33 Nunung Cipta Dainy, Fauza Rizqiya, Walliyana Kusumaningati, Wilda Yunieswati Perbedaan Status Gizi...

children and adolescents. Journal of the American Dietetic Association, 105(5), 743-760.

https://doi.org/10.1016/j.jada.2005.02.00 7

Rosyidah, Z., Ririn Andrias, D., \& Gizi Kesehatan Fakultas Kesehatan, D. (2013). Jumlah Uang Saku Dan Kebiasaan Melewatkan Sarapan Berhubungan Dengan Status Gizi Lebih Anak Sekolah Dasar. 1-6.

Suryaalamsah, I. I., Kushargina, R., Stefani, M. (Gerakan Membawa Bekal Makan Dan Minum Ke Sekolah) Sebagai Upaya Pemenuhan Gizi Murid Sdn Pesanggrahan 02 Jakarta Selatan. (September 2019). Prosiding Semnaskat UMJ.

http://jurnal.umj.ac.id/index.php/semnask at.

Utter, J., Scragg, R., Mhurchu, C. N., \& Schaaf, D. (2007). At-Home Breakfast Consumption among New Zealand Children: Associations with Body Mass Index and Related Nutrition Behaviors \{ A figure is presented\}. Journal of the American Dietetic Association, 107(4), 570-576.

https://doi.org/10.1016/j.jada.2007.01.01 0 